\title{
Adolescência, Escolha Profissional e Identificação: Uma Revisão Sistemática
}

\author{
Mirian Marques Andrade ${ }^{1}$; Thércia Lucena Grangeiro Maranhão ${ }^{2}$; Janilda dos Santos Barbosa ${ }^{3}$; \\ Hermes Melo Teixeira Batista ${ }^{4}$; Andreza Oliveira Santana ${ }^{5}$
}

\begin{abstract}
Resumo: O presente artigo tem como objetivos investigar quais fatores exercem influência na escolha profissional do adolescente; pretende-se também estudar as transformações sócias históricas da Orientação Profissional; compreender a adolescência e suas motivações e apresentar o conceito de identificação e sua relação com a escolha profissional, à luz da psicanálise. A pesquisa foi delineada por meio da revisão sistemática por metassintese onde foram selecionados artigos nas bases de dados acadêmicos Scielo e Google acadêmico, publicados no período de 2005 a 2014, utilizando-se os descritores: Orientação Profissional, escolha profissional e adolescência. Os fatores elencados como influentes foram: políticos, sociais, culturais, tecnológicos, econômicos, educacionais, individuais, psicológicos e familiares.
\end{abstract}

Palavras - chave: Orientação Profissional; escolha profissional; adolescência.

\section{Adolescence, Professional Choice and Identification: A Systematic Review}

\begin{abstract}
This article aims to investigate which factors influence the choice of the professional teenager; It also aims to study the historical partners transformations vocational guidance; understanding the adolescence and their motivations and introduce the concept of identification and its relationship with the professional choice, in light of psychoanalysis. The research was outlined through the systematic review by metassintese where articles were selected on the basis of academic Scielo and Google Scholar data, published in the period from 2005 to 2014, using the key words: vocational guidance, occupational choice and adolescence. Listed as influential factors were: political, social, cultural, technological, economic, educational, individual, psychological and family.
\end{abstract}

Keywords: Professional Orientation; professional choice; adolescence.

\section{Introdução}

Optar por uma profissão é decidir sobre "quem se quer ser", portanto faz-se necessário ter autoconhecimento para que a decisão tomada possa ser a mais adequada. Para isso é preciso ainda conhecer a realidade social na qual estão inseridos, os fatores que podem influenciara escolha profissional.

\footnotetext{
${ }^{1}$ Graduanda de Psicologia, Unileão - miriiandrade@hotmail.com

${ }^{2}$ Graduada em Psicologia pela Faculdade de Ciências Humanas (ESUDA) ; Especialista em Gestão do Trabalho na Saúde pela Escola de Saúde Pública do Estado do Ceará ; Mestranda da Faculdade de Medicina do ABC-SP (FMABC),Atualmente docente e Orientadora do Centro Universitário Dr. Leão Sampaio (UNILEÃO); Vice-líder Iniciação Científica pelo Grupo de Pesquisa em Psicologia Humanista (GPPH) - thercia@leaosampaio.edu.br;

${ }^{3}$ Professora em juazeiro do Norte-CE.

${ }^{4}$ Médico pela Universidade Federal do Ceará - UFC. Médico do Hospital Regional do Cariri. Mestrado e Doutorando pela Faculdade de Medicina do ABC. Santo André-SP. Contato: hermesmelo@oi.com.br

${ }^{5}$ Médica do Hospital Regionl do Cariri. Juazeiro do Norte - CE.
} 
Id on Line Revista Multidisciplinar e de Psicoloqia

Id on Line Multidisciplinary Journal and Psycology

Tendo em vista a relevância do trabalho enquanto categoria de constituição do sujeito e as inúmeras transformações neste universo, orientar-se profissionalmente tem se tornado uma tarefa cada vez mais complexa e emergente na vida humana (GUICHARD, 2011).

Diante desses apontamentos, o presente trabalho se propôs a investigar quais fatores exercem influência na escolha profissional do adolescente, por meio de uma revisão sistemática por metassíntese. Pretende-se também estudar as transformações sócias históricas da Orientação Profissional; compreender a adolescência e suas motivações, apresentar o conceito de identificação e sua relação com a escolha profissional, à luz da psicanálise.Para isso foram selecionados artigos nas bases de dados do Google acadêmico e Scielo publicados no período de 2005 a 2014, utilizando-se os descritores: escolha profissional, adolescência e orientação profissional.

A sistematização da pesquisa visa propiciar, a partir dos dados coletados,reflexões e discussões sobre as práticas que estão sendo realizadas nos processos de Orientação Profissional, apontando para as especificidades das fases do desenvolvimento humano e o contexto sociocultural em que a escolha venha acontecer. Acredita-se que a pesquisa a ser realizada possibilitará aos orientadores profissionais lançar um olhar mais profundo sobre as relações que se estabelecem nesta complexa etapa da vida,o que pode contribuir para que os orientandos encontrarem novos caminhos que colaborem para o seu desenvolvimento pessoal e profissional.

A pesquisa é fruto do interesse despertado pela orientação profissional, a partir da realização de um projeto de intervenção na área, no contexto escolar com adolescentes pré-vestibulandos. Outro aspecto que contribui para a realização da pesquisa foi a aproximação das produções literárias sobre o trabalho e sua relação com a perspectiva psicanalítica, os questionamentos e reflexões por elas acarretadas sobre a função estruturante que este assume nas relações humanas, alertando assim para pertinência do processo de orientação profissional.

\section{Metodologia}

A presente pesquisa se propôs a uma revisão sistemática por metassíntese sobre a relação da adolescência e a escolha profissional, a partir de dados coletados no período de 2005 - 2014. Esta modalidade de pesquisa tem cunho bibliográfico e se realiza por meio da revisão de resultados de pesquisas, objetivando tecer articulações para propor um novo conhecimento. A revisão por metassintese estrutura-se pelas seguintes etapas: definição de objeto, definição das fontes de pesquisa, estabelecimento dos tipos de documentos a serem consultados e composição da amostra (OLIVEIRAet $a l, 2015)$ 
Para esta sistematização utilizou-se os artigos científicos das bases de dados virtuais Scielo (Scientific Eletronic Online) e Google acadêmico e como material de apoio livros relacionados ao tema, somando o total de 9. A busca a partir dos critérios de inclusão disponibilizou 56 artigos dos quais foram selecionados 14. As palavras-chave utilizadas foram: adolescência, escolha profissional e orientação profissional. Os critérios de inclusão estabelecidos foram: a) documentos produzidos no período de 2005 a 2014; b) artigos completos e c) produções científicas que continham um ou mais das palavras-chave no título, no resumo e/ou nas palavras chaves. Como critérios de exclusão se definiram: a) produções anteriores a 2005, b) dissertações e c) artigos que apesar de conter as palavras-chave enfatizassem outros assuntos.

Objetivando uma compreensão aprimorada dos dados coletados, realizou-se uma leitura superficial dos títulos, frases e resumos, seguida por uma leitura mais criteriosa para a divisão dos artigos em categorias, assim como propõe Oliveira et al (2015). Foram estabelecidas três categorias intituladas: adolescência; fatores de influência no processo de escolha profissional e identificação. Para cada categoria estabelecida construiu-se uma tabela de dados contendo informações sobre autor, titulo, ano e resultados.

Quadro 1 Fluxuograma da pesquisa

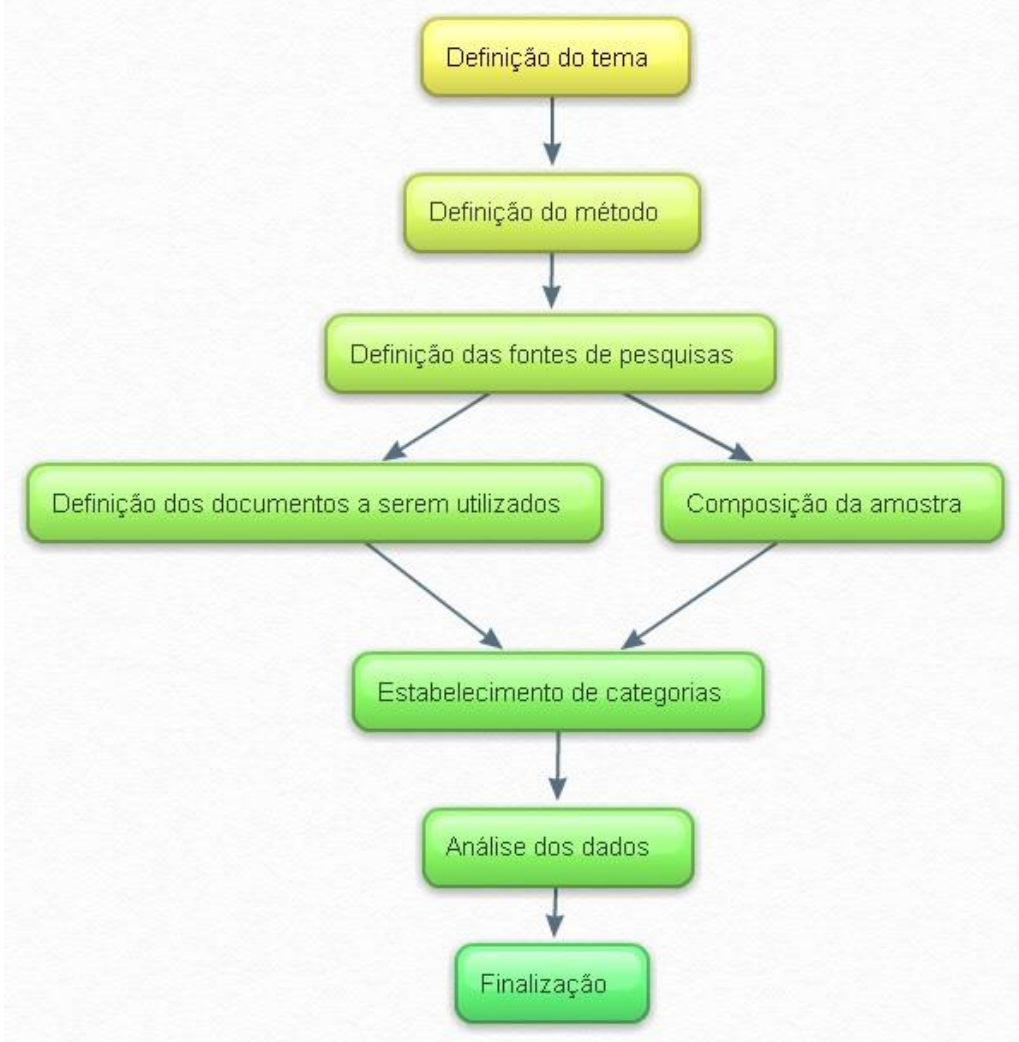

Fonte: Andrade (2016) 
Tabela. Artigos que compõe a categoria 1- Adolescência

\begin{tabular}{|c|c|c|c|}
\hline Autor & Titulo & Ano & Resultados \\
\hline COUTINHO & $\begin{array}{l}\text { A adolescência na } \\
\text { contemporaneidade } \\
: \text { ideal cultural ou } \\
\text { sintoma social }\end{array}$ & 2005 & $\begin{array}{l}\text { Os adolescentes em suas fratrias, } \\
\text { podem assumir diversas posições frente } \\
\text { ao sintoma social. }\end{array}$ \\
\hline SANTOS & $\begin{array}{l}\text { O papel da família } \\
\text { e dos pares na } \\
\text { escolha profissional }\end{array}$ & 2005 & $\begin{array}{l}\text { Uma parte dos adolescentes } \\
\text { demonstrou a sua insegurança diante } \\
\text { das opiniões da sua família e do seu } \\
\text { outro social, mesmo após a sua escolha } \\
\text { ter sido feita. }\end{array}$ \\
\hline LARA et al & $\begin{array}{l}\text { O adolescente e a } \\
\text { escolha } \\
\text { profissional: } \\
\text { compreendendo o } \\
\text { processo de decisão }\end{array}$ & 2005 & $\begin{array}{l}\text { Além das dificuldades } \\
\text { Influencias, critérios, facilitadores e } \\
\text { sentimentos que os acompanham, os } \\
\text { adolescentes estão preocupados em } \\
\text { fazer uma escolha satisfatória, em que } \\
\text { eles procuram conciliar seus gostos e } \\
\text { aptidões coma situação em que se } \\
\text { encontram. }\end{array}$ \\
\hline $\begin{array}{l}\text { TEIXEIRA E } \\
\text { HASHIMOT } \\
\text { O }\end{array}$ & $\begin{array}{lr}\text { Família e } & \text { escolha } \\
\text { profissional: } & \text { a } \\
\text { questão espacial, } \\
\text { temporal } & \text { e } \\
\text { significado } & \text { dos } \\
\text { nomes } & \\
\end{array}$ & 2005 & $\begin{array}{l}\mathrm{O} \text { fator afetivo torna-se relevante, } \\
\text { sendo um aspecto facilitador para viver } \\
\text { o presente, com base no passado, } \\
\text { possibilitando projeções futuras. }\end{array}$ \\
\hline $\begin{array}{l}\text { BARRETO E } \\
\text { AIELLO- } \\
\text { VAISBERG }\end{array}$ & $\begin{array}{l}\text { Escolha } \\
\text { profissional e } \\
\text { dramática do viver } \\
\text { adolescente }\end{array}$ & 2007 & $\begin{array}{l}\text { A prática atual parece realmente } \\
\text { estabelecer uma divisão drástica entre o } \\
\text { mundo infantil e adulto, contribuindo } \\
\text { para o medo do futuro e para as } \\
\text { dificuldades do estabelecimento de } \\
\text { metas. }\end{array}$ \\
\hline FROTA & $\begin{array}{lr}\begin{array}{l}\text { Diferentes } \\
\text { concepções }\end{array} & \text { da } \\
\text { infância } & \mathrm{e} \\
\text { adolescência: } & \mathrm{a} \\
\text { importância } & \text { da } \\
\text { historicidade } & \text { para } \\
\text { sua construção } & \\
\end{array}$ & 2007 & $\begin{array}{l}\text { Elaborar conclusões sobre a concepção } \\
\text { atual de infância e da adolescência na } \\
\text { contemporaneidade evidencia-se uma } \\
\text { tarefa impossível de ser levada a cabo. }\end{array}$ \\
\hline $\begin{array}{l}\text { ALMEIDA E } \\
\text { PINHO }\end{array}$ & $\begin{array}{l}\text { Adolescência, } \\
\text { família e escolhas: } \\
\text { implicações na } \\
\text { orientação } \\
\text { profissional }\end{array}$ & 2008 & $\begin{array}{l}\text { Adolescentes cujos pais participaram } \\
\text { dos encontros se mostraram mais } \\
\text { calmos, seguros e menos ansiosos } \\
\text { frente ás suas escolhas. }\end{array}$ \\
\hline
\end{tabular}


Tabela: artigos que compõe a categoria 2 - Fatores influentes no processo de escolha

\begin{tabular}{|c|c|c|c|}
\hline AUTOR & TÍTULO & ANO & RESULTADOS \\
\hline SANTOS & $\begin{array}{l}\text { O papel da família e } \\
\text { dos pares na escolha } \\
\text { profissional }\end{array}$ & 2005 & $\begin{array}{l}\text { Uma parte dos } \\
\text { adolescentes } \\
\text { demonstrou a sua } \\
\text { insegurança diante das } \\
\text { opiniões da sua família } \\
\text { e do seu outro social, } \\
\text { mesmo após a sua } \\
\text { escolha ter sido feita. }\end{array}$ \\
\hline LARA et al & $\begin{array}{l}\text { O adolescente e a } \\
\text { escolha profissional: } \\
\text { compreendendo o } \\
\text { processo de decisão }\end{array}$ & 2005 & $\begin{array}{l}\text { Além das dificuldades } \\
\text { Influencias, critérios, } \\
\text { facilitadores res } \\
\text { sentimentos que os } \\
\text { acompanham, os } \\
\text { adolescentes estão } \\
\text { preocupados em fazer } \\
\text { uma escolha } \\
\text { satisfatória, em que } \\
\text { eles procuram conciliar } \\
\text { seus gostos e aptidões } \\
\text { coma situação em que } \\
\text { se encontram. }\end{array}$ \\
\hline $\begin{array}{ll}\text { TEIXEIRA } & \text { E } \\
\text { HASHIMOTO } & \end{array}$ & $\begin{array}{l}\text { Família e escolha } \\
\text { profissional: a questão } \\
\text { espacial,temporal e o } \\
\text { significado dos nomes }\end{array}$ & 2005 & $\begin{array}{l}\text { O fator afetivo torna-se } \\
\text { relevante, sendo um } \\
\text { aspecto facilitador para } \\
\text { viver o presente, com } \\
\text { base no passado, } \\
\text { possibilitando } \\
\text { projeções futuras. }\end{array}$ \\
\hline FROTA & \begin{tabular}{lr}
\multicolumn{2}{l}{ Diferentes concepções } \\
da infância & e \\
adolescência: & a \\
importância & da \\
historicidade para & sua \\
construção &
\end{tabular} & 2007 & $\begin{array}{l}\text { Elaborar conclusões } \\
\text { sobre a concepção } \\
\text { atual de infância e da } \\
\text { adolescência na } \\
\text { contemporaneidade } \\
\text { evidencia-se uma } \\
\text { tarefa impossível de ser } \\
\text { levada a cabo. }\end{array}$ \\
\hline PEREIRA E GARCIA & $\begin{array}{l}\text { Amizade e escolha } \\
\text { profissional: influencia } \\
\text { ou cooperação? }\end{array}$ & 2007 & $\begin{array}{l}\text { As relações } \\
\text { amizades entre } \\
\text { profissional escolha } \\
\text { mostram muito mais } \\
\text { complexas, com um } \\
\text { papel de destaque para } \\
\text { a cooperação entre } \\
\text { adolescentes. }\end{array}$ \\
\hline ALMEIDA E PINHO & $\begin{array}{l}\text { Adolescência, família e } \\
\text { escolhas: implicações } \\
\text { na orientação } \\
\text { profissional }\end{array}$ & 2008 & $\begin{array}{lr}\text { Adolescentes } & \text { cujos } \\
\text { pais participaram } & \text { dos } \\
\text { encontros } & \text { se } \\
\text { mostraram } & \text { mais } \\
\end{array}$ \\
\hline
\end{tabular}




\begin{tabular}{|c|c|c|c|}
\hline & & & $\begin{array}{l}\text { calmos, seguros e } \\
\text { menos ansiosos frente } \\
\text { ás suas escolhas. }\end{array}$ \\
\hline SOARES et al & $\begin{array}{lr}\text { O conceito } & \text { de } \\
\text { identificação } & \text { no } \\
\text { processo de } & \text { escolha } \\
\text { profissional } & \end{array}$ & 2010 & $\begin{array}{l}\text { O adolescente que o } \\
\text { vestibulando ainda é, } \\
\text { vive mais uma vez a } \\
\text { renúncia do } \\
\text { investimento libidinal } \\
\text { dos pais, renuncia que } \\
\text { se faz pela } \\
\text { identificacão. }\end{array}$ \\
\hline $\begin{array}{ll}\text { ALMEIDA } & \text { E } \\
\text { MAGALHÃES } & \end{array}$ & $\begin{array}{l}\text { Escolha profissional na } \\
\text { contemporaneidade: } \\
\text { projeto individual e } \\
\text { projeto familiar }\end{array}$ & 2011 & $\begin{array}{l}\text { O trabalho de } \\
\text { orientação profissional } \\
\text { nessa etapa da vida } \\
\text { pode ser essencial, no } \\
\text { sentindo de auxiliar o } \\
\text { jovem a pensar sobre } \\
\text { as influencias sociais e } \\
\text { familiares na escolha, } \\
\text { buscando clarificar os } \\
\text { vínculos de lealdade } \\
\text { existentes na família. }\end{array}$ \\
\hline ALMEIDA E SILVA & $\begin{array}{l}\text { Influência dos pais no } \\
\text { processo de escolha } \\
\text { dos filhos: uma revisão } \\
\text { de literatura }\end{array}$ & 2011 & $\begin{array}{l}\text { A influência dos pais } \\
\text { nos processos de } \\
\text { escolha profissional } \\
\text { dos filhos ocorre } \\
\text { continuamente nos } \\
\text { processos de interação } \\
\text { dentro dos grupos } \\
\text { familiares, algo } \\
\text { iniciado na infância. }\end{array}$ \\
\hline MAGALHÃES et al & $\begin{array}{l}\text { Relação entre estilos } \\
\text { parentais, } \\
\text { instabilidades de metas } \\
\text { e indecisão vocacional } \\
\text { em adolescentes }\end{array}$ & 2012 & $\begin{array}{l}\text { Estilos parentais } \\
\text { influenciam no } \\
\text { desenvolvimento de } \\
\text { recursos fundamentais } \\
\text { de personalidade, tais } \\
\text { como a capacidade de } \\
\text { estabelecer e manter } \\
\text { metas, que por sua vez } \\
\text { tem impacto em } \\
\text { variáveis } \\
\text { desenvolvimento do } \\
\text { vocacional como a } \\
\text { decisão de carreira. }\end{array}$ \\
\hline
\end{tabular}


Id on Line Revista Multidisciplinar e de Psicoloqia

Id on Line Multidisciplinary Journal and Psycology

Tabela. Artigos que compõe a categoria 3 - Identificação

\begin{tabular}{|c|c|c|c|}
\hline AUTOR & TTULO & ÁNO & RESULTADOS \\
\hline COUTINHO et al & $\begin{array}{l}\text { Ideais e identificações } \\
\text { em adolescentes de } \\
\text { Bom Retiro }\end{array}$ & 2005 & $\begin{array}{l}\text { As identificações e os } \\
\text { ideias atrelados a } \\
\text { esfera familiar são } \\
\text { predominantes no } \\
\text { discurso dos jovens, } \\
\text { sendo inclusive } \\
\text { transpostos para as } \\
\text { figuras do mundo } \\
\text { publico eleitas por eles, } \\
\text { estas na maioria das } \\
\text { vezes representadas } \\
\text { por figuras midiáticas } \\
\text { distantes e/ou vazias. }\end{array}$ \\
\hline COUTINHO & $\begin{array}{l}\text { A adolescência na } \\
\text { contemporaneidade: } \\
\text { ideal cultural ou } \\
\text { sintoma social }\end{array}$ & 2005 & \begin{tabular}{lr} 
Os adolescentes em \\
suas fratrias,podem \\
assumir & \multicolumn{2}{c}{ diversas } \\
posições frente ao \\
sintoma social.
\end{tabular} \\
\hline SOARES et al & $\begin{array}{lr}\text { O conceito } & \text { de } \\
\text { identificação } & \text { no } \\
\text { processo de } & \text { escolha } \\
\text { profissional } & \end{array}$ & 2010 & $\begin{array}{l}\text { O adolescente que o } \\
\text { vestibulando ainda é, } \\
\text { vive mais uma vez a } \\
\text { renúncia ra do } \\
\text { investimento libidinal } \\
\text { dos pais, renuncia que } \\
\text { se faz pela } \\
\text { identificação. }\end{array}$ \\
\hline
\end{tabular}

\section{Breve Histórico da Orientação Profissional}

O trabalho enquanto categoria de construção subjetiva tem grande importância, inicialmente este era concebido como a atividade que assegurava as necessidades básicas humanas, assumindo posteriormente uma concepção econômica aliada à produção de riqueza através do emprego. Em decorrência das mudanças nos modos de produção, as relações desenvolvidas sob os moldes do capitalismo, são caracterizadas pela precarização e fragmentação, o que afeta o processo de constituição subjetiva dos sujeitos envolvidos nessas relações (AQUINO, 2005; COUTINHO et $a l, 2001)$.

Com o processo de industrialização, o mundo do trabalho modificou-se, dando aos indivíduos a oportunidade de escolherem um oficio e se realizarem por meio desse. Outrora, a ocupação profissional de um sujeito era concernente ao nível social de sua família, sendo esta transmitida de 
Id on Line Revista Multidisciplinar e de Psicoloqia

Id on Line Multidisciplinary Journal and Psycology

geração a geração, assim, escolher uma profissão é algo novo, tendo se tornado uma exigência social orientar-se profissionalmente (GUICHARD, 2011; MOURA, 2011).

Apesar de suas origens estarem referenciadas ao ano de 1902 na Europa, a Orientação Profissional nasce oficialmente entre 1907 e 1909 com a criação do primeiro centro de Orientação Profissional norte-americano e a publicação de um livro sobre o mesmo assunto de Frank Parsons. Considerado como o pai da Orientação Profissional, Parsons (1854/1909) trouxe a esta os conceitos da Psicologia e Pedagogia, e em seu livro propunha que o referido processo deveria considerar os aspectos ligados aos indivíduos, às ocupações e a relação entre estes(SPARTA, 2003).

As ocorrências das duas grandes Guerras Mundiais contribuíram para a consolidação e expansão da Orientação Profissional como área de atuação devido as necessidades e mudanças sociais acarretadas.O Brasil, com relação a América Latina, juntamente com a Argentina foram precursores neste campo (MOURA, 2011; NEIVA, 2013). Com o desenvolvimento dos testes psicológicos, o processo de Orientação Profissional passou a ser influenciado pela Psicologia diferencial e pela Psicometria, concentrando-se na realização de diagnósticos e prognósticos para a adequada recomendação de profissões/ocupações, sendo este modelo de atuação decorrente da Teoria do Traço e Fator(SPARTA,2003).

Somente na década de 1940, com a apresentação dos pressupostos da Teoria Centrada no Cliente, de Carl Rogers, é que as práticas de Orientação Profissional começaram a sofrer mudanças, aderindo a um modelo de intervenção considerado como não diretivo, surgiram na década seguinte, teorias para embasar este campo a partir das discussões sobre escolha profissional.

A Teoria Do Desenvolvimento Vocacional de Ginzberget al (1951) é considerada como a precursora destas, tendo ainda a Teoria Do Desenvolvimento Vocacional de Donald Super (1953) e a Teoria Tipológica de JonhHolland (1959) (SPARTA,2003).

Apesar de possuírem o mesmo nome, as Teorias de Ginzberget al(1951) e Super (1953) se diferenciam significativamente. A primeira teoria compreende a escolha profissional como um processo do desenvolvimento humano que se dá entre o final da infância e no inicio da vida adulta. Em contrapartida a teoria de Super considera que esse processo acontece durante toda a vida por meio de períodos do desenvolvimento vocacional e da realização das obrigações do processo evolutivo. A teoria tipológica estabelece uma relação entre os interesses profissionais e as características de personalidade, para delinear grupos e espaços de trabalho (SPARTA,2003).

Assim, a Psicologia Vocacional pode ser dividida em dois períodos: o primeiro datado entre 1900 e 1950, sendo caracterizada pelo uso da Psicometria; e o segundo período datado de 1950 até os dias atuais, sendo caracterizado pelas novas compreensões, no que diz respeito á escolha profissional, 
Id on Line Revista Multidisciplinar e de Psicoloqia

Id on Line Multidisciplinary Journal and Psycology

propostas por algumas concepções teóricas, das quais se destacam a Psicodinâmica, de base psicanalítica, Decisional e Desenvolvimentista(NEIVA, 2013; SPARTA, 2003) .

A Orientação Profissional brasileira nasceu em 1924 atrelada a Psicologia Aplicada, e posteriormente entre as décadas de 30 e 40 ligou-se a Educação. A aproximação entre as áreas se deu a partir da necessidade de qualificar a mão de obra para o comércio, a indústria e a agricultura. Seu maior desenvolvimento deu-se também a partir da década de 1940, com a Fundação Getúlio Vargas, que se dedicava ao estudo da relação entre a organização do Trabalho e a psicologia. Vale destacar que o desenvolvimento da Ciência psicológica influenciou o campo da Orientação Profissional no país, ligando o processo a Psicologia Clínica (SPARTA, 2003).

Com as mudanças no modelo político e econômico do país, se difundiu a ideia que as propostas educacionais deveriam se direcionar à população como um todo. A psicometria se desenvolveu neste cenário, propiciando a criação do Instituto de Seleção e Orientação Profissional. Este tinha como objetivo maior proporcionar adequação entre o indivíduo e a atividade laboral, por meio da identificação, do que se compreendia na época como vocações e das exigências da atividade. As ações eram balizadas a partir da Teoria da Administração Cientifica do trabalho, desconsiderando os aspectos idiossincráticos dos sujeitos e os fatores sociais (ABADE, 2005).

A partir da década de 70, a psicologia amplia sua área de atuação e o processo de Orientação Profissional passa a ser avaliado a partir de uma perspectiva crítica, almejando a estruturação de um referencial teórico inerente ao campo, teceram-se discussões sobre a escolha profissional compreendida como um processo, e a maturidade dos indivíduos para a tomada de decisão. As produções de Bohoslavsky (1971) foram de suma importância para esta estruturação assim como para as novas práticas. Nos anos 90, o ISOP foi abolido e fundou-se a Associação Brasileira de Orientação profissional (ABOP) com o objetivo de abordar tanto a formação do orientador profissional como o estabelecimento de diretrizes para a área (ABADE, 2005).

Assim, os estágios da evolução da Orientação Profissional brasileira podem ser classificados como informativo, em relação às profissões; psicométrico, com a valorização dos aspectos individuais; clínico, considerando o potencial do indivíduo, político e social destacando a importância da realidade onde se dá a escolha profissional (LEHMAN, 2010).

A autora discorre sobre o desenvolvimento de um quinto estagio, denominado Era de Kairós, que traz consigo a necessidade de intervenções que visem a elaboração de projetos profissionais que se sobreponham à fragilidade das instituições sociais, buscando articular o individuo e os sistemas, atentando para a as transformações decorrentes do processo de globalização, suas implicações na relação homem-trabalho e a relevância assumida pela atividade laboral enquanto categoria de constituição (LEHMAN, 2010). 
Id on Line Revista Multidisciplinar e de Psicoloqia

Id on Line Multidisciplinary Journal and Psycology

Diante dos desafios apresentados a Orientação profissional pode ser compreendida a partir da proposta de Ribeiro (2011 apud NEIVA, 2013. p. 21).

[...] um processo de ajuda de caráter mediador e cooperativo entre um profissional preparado teórica e tecnicamente com as competências básicas exigidas e desenvolvidas para um orientador profissional e um sujeito ou grupo de sujeitos que necessite de auxilio quanto a elaboração e consecução do seu projeto de vida profissional/ocupacional com todos os aspectos envolvidos do seu comportamento vocacional( conhecimento de seu processo de escolha, autoconhecimento, conhecimento do mundo do trabalho e dos modelos de elaboração de projetos).

Esta conceituação exprime a importância do preparo profissional daquele que irá mediar o processo, Silva (1992) discorre sobre este assunto e enuncia três eixos que embasam a formação do orientador, que se assegurados possibilitará auxiliar o orientando a ter uma escolha consciente e autônoma. A saber,são: consistente base teórico-técnica, clareza no conceito de homem no mundo e resolução dos conflitos pessoais no que diz respeito a escolha profissional. É válido mencionar que em nosso país as intervenções em Orientação Profissional são realizadas por psicólogos e pedagogos e o termo considerado mais adequado a se utilizar é "orientação profissional" com o intuito de apontar para uma nova perspectiva da área distanciando-se da concepção de vocação profissional (SPARTA, 2003; MOURA, 2011).

Assim como Silva (1992), que enunciou os referidos eixos, Guichard (2011) apresenta três instâncias das quais decorrem as intervenções em Orientação Profissional, a primeira forma de intervenção pode ser considerada pedagógica e tem por objetivo informar sobre as formas de organização do trabalho e do emprego, o segundo nível de intervenção tem como finalidade facilitar o processo de construção de relações específicas consigo mesmo e com atividades ligadas ao trabalho, levando em consideração experiências do sujeito, possibilitando a reflexão sobre a perspectiva profissional e a maneira pela qual se adquiriu as competências.

$\mathrm{O}$ autor afirma que as intervenções desse nível devem ser realizadas por profissionais com formação em psicologia, especificamente em aconselhamento/orientação. O último nível tem por objetivo promover reflexões sobre os aspectos que dão sentido à vida, não se detendo apenas ao âmbito profissional, buscando integrá-lo com as outras esferas da vivência humana, as intervenções deste nível visam a autonomia do sujeito, auxiliando ao mesmo em sua autorreflexão e na problematização das determinações sociais (GUICHARD, 2011).

O fato do processo decisório geralmente acontecer na adolescência, e desta possibilitar ao sujeito que escolhe uma nova posição frente ao mundo, nos permite conceber o processo de Orientação Profissional como um moderno rito preliminar de passagem à vida adulta (SILVA; SOARES, 2001). O ritual de passagem efetivo se dá a partir do momento em que o indivíduo assume 
Id on Line Revista Multidisciplinar e de Psicoloqia

Id on Line Multidisciplinary Journal and Psycology

um lugar social sustentado uma escolha profissional tendo, assim, finalizado a elaboração do luto infantil.

\section{O Viver Adolescente e o Processo de Escolha}

Compreendendo a adolescência a partir do contexto ocidental contemplamos uma fase marcada por mudanças e angústias que impelem ao crescimento pessoal, trazendo consigo a vivência de lutos (SILVA; SOARES, 2001), o conceito de adolescência é resultante de uma construção social que teve seu reconhecimento no ciclo vital no século XX. O mesmo se apresenta de maneira peculiar em cada contexto sendo ainda afetado por fatores culturais e econômicos (PAPALIA; FELDMAN, 2013).

Apesar de ser concebido como um fenômeno global não há um consenso sobre o início e término da referida fase, isso devido à complexidade de fatores envolvidos como os fisiológicos, biológicos, cognitivos e psicossociais. Cabe ao indivíduo lidar com as transformações acarretadas por estes fatores, iniciadas pelo processo de puberdade. No entanto se compreende como adolescente o sujeito que tem a idade entre 11 e 21 anos (CAMPOS, 2011; PAPALIA; FELDMAN, 2013).

Em sua perspectiva teórica de cunho psicanalítico, Erikson (1902) discorre sobre a adolescência a partir das características presentes no $5^{\circ}$ (quinto) estágio de desenvolvimento evolutivo denominado identidade versus difusão de papeis ou identidade versus confusão de identidade. Todos os estágios propostos por Erikson trazem consigo crises a serem enfrentadas. A que se faz presente neste estágio refere-se a construção de identidade, a partir da integração das identificações passadas. Cabe ressaltar que a formação da identidade ocupacional é dependente dessa construção e a resolução positiva da crise é a atividade primordial a ser realizada nesta fase evolutiva (ALMEIDA; PINHO, 2008; CAMPOS, 2011; PAPALIA; FELDMAN, 2013).

A crise é composta pela vivência de sete momentos críticos que devem ter resoluções positivas. Dentre estes se encontra o período denominado aprendizagem versus paralisia operacional, que faz menção às escolhas relacionadas ao trabalho. As conquistas resultantes do estágio produtividade versus inferioridade servem como uma base que possibilita avaliar a perspectiva vocacional (PEREIRA, 2005).

Estando a crise solucionada de modo positivo, a partir da construção do senso de identidade do ego, o indivíduo alcançará a identidade psicossocial, que permitirá ao mesmo ter uma visão sobre si mesmo e suas perspectivas futuras. O modo pelo qual o indivíduo enfrentará a crise está diretamente relacionado com o tratamento recebido pelas figuras parentais/cuidadores durante a infância. Pois a 
Id on Line Revista Multidisciplinar e de Psicoloqia

Id on Line Multidisciplinary Journal and Psycology

prevalência de aspectos como confiança, desconfiança, autonomia ou vergonha, iniciativa ou dúvida, produtividade ou culpa e inferioridade, resultantes das vivências dos estágios anteriores influenciarão na construção e estabelecimento de uma identidade psicossocial integrada (PEREIRA,2005).

Ocorrem mudanças também no que se refere ao manejo do tempo para as relações interpessoais. Os adolescentes tendem a passar mais tempo com o grupo de amigos do que com a família; tal aspecto igualmente se relaciona com o processo de construção de identidade (PAPALIA; FELDMAN, 2013). Apesar de todas as transformações e desafios impostos a relação pais -filho durante a adolescência, o convívio tende a ser bem-sucedido a depender da posição assumida pelos pais (PEREIRA,2005).

\section{Sobre os fatores influentes}

Os dilemas frente ao momento de escolha não são inerentes apenas a fase da adolescência, uma vez que o sujeito tende a avaliar a escolhas nas fases evolutivas posteriores; mas este momento se apresenta mais criticamente para o adolescente por todos os conflitos deste período e por ser uma situação singular na qual a decisão a ser tomada terá implicações significativas no futuro. Porquanto escolher uma profissão é escolher um lugar social, é optar pela forma na qual irá se reconhecer e ser reconhecido nas diversas esferas de convívio(LARA et al, 2005).

Apesar de reconhecer a importância dos aspectos culturais e socioeconômicos, a existência das divisões sociais e a implicação destes fatores sobre a questão da escolha profissional se faz pertinente afirmar a existência da possibilidade efetiva de escolha, mesmo diante de oportunidades restritas. Portanto a Orientação Profissional buscará auxiliar o sujeito adolescente na conciliação entre suas pretensões e o mundo do trabalho(BARRETO; AIELLO-VAISBERG, 2007).

Frente a escolha profissional que o adolescente deve fazer, se vê confrontado em um período de crise com sua visão de mundo, autoimagem, com a multiplicidade de profissões e com as opiniões provenientes do grupo família e social (ALMEIDA; PINHO, 2008). Discorrendo sobre os fatores que intervém na escolha profissional pode-se elencar: os políticos, econômicos, sociais, educacionais, os familiares e psicológicos. Os fatores políticos fazem menção à relação estabelecida entre a política governamental e a educação; os econômicos dizem respeito ao sistema econômico, as relações de produção e suas implicações para a educação; os sociais referem-se a divisão de classes, o papel assumido pelo ensino superior e a relação sociedade-família; e os fatores educacionais referem-se ao ambiente escolar, aos métodos de ensino, aos aspectos ligados aos vestibular entre outros aspectos (SOARES, 2002; LEHMAN,2010). 
Id on Line Revista Multidisciplinar e de Psicoloqia

Id on Line Multidisciplinary Journal and Psycology

A presente pesquisa discorrerá sobre os fatores familiares, psicológicos e educacionais, devido à produção literária disponível sobre os mesmos. No que diz respeito aos fatores psicológicos será abordado à relação entre pares, tendo em vista a apresentação da crise da adolescência e as questões ligadas a formação da identidade. Com relação aos fatores educacionais se discorrerá sobre a influência do ambiente escolar.

É preciso assegurar sobre a relevância da realização de estudos mais acurados, no que diz respeito à influência familiar quer seja de forma consciente ou inconsciente; uma vez que os jovens podem optar por uma profissão sem distinguir sobre as influências decorrentes do seu contexto familiar. O imperativo da escolha atinge a família, e os pais tendem a padecer com o conflito vivenciado pelos filhos, já que as expectativas, sonhos e projetos são perceptíveis nos relatos de ambas partes envolvidas na situação de escolha (SOARES, 2002; SANTOS, 2005; ALMEIDA; PINHO, 2008). O projeto de carreira não deve ser concebido como individual, pois todos indivíduos fazem parte de um contexto histórico e sociocultural e familiar, onde se estabelecem as relações de influência. (ALMEIDA; MAGALHAES, 2011)

É evidente a importância do contexto familiar no desenvolvimento psicossocial do adolescente, por todas as expectativas que este comporta, a decisão a ser tomada irá refleti-las, podendo assim demonstrar também o desejo familiar que por sua vez pode divergir do desejo daquele que escolhe. Diante desta importância, e da possibilidade deste fator se apresentar como um fator positivo ou negativo para o processo decisório, o mesmo tem sido alvo de estudos por diversos teóricos em culturas diferentes (ALMEIDA; PINHO, 2008).

As escolhas profissionais dos pais e suas experiências no mundo do trabalho, influenciam na construção dos conceitos sobre as profissões. As opiniões, valores e crenças sobre estas decorrentes do âmbito familiar podem se expressar de maneira explícita ou implícita; o fato das influências se apresentarem explicitamente não garante uma escolha assertiva por parte do adolescente. Pois o sujeito pode agir em conformidade ao projeto profissional elaborado pela família, não refletindo sobre o mesmo (ALMEIDA; PINHO, 2008).

Corroborando com os autores citados anteriormente, Santos (2005) afirma sobre as influencias das experiências profissionais de familiares sobre a construção dos valores acerca das atividades ocupacionais. A autora expõe ainda que a escolha pode ser compreendida como uma forma do adolescente demonstrar lealdade à família. Somando-se a este fator, o estilo parental também tem suas implicações neste processo.

Magalhaes, Alvarenga e Teixeira (2012) apontam a existência de influencias direta e indireta relacionada às condições socioeconômicas e culturais e a emissões de opiniões por parte dos pais. E as formas como estas irão se apresentar estão ligadas ao estilo parental. Entende-se por estilo parental os 
Id on Line Revista Multidisciplinar e de Psicoloqia

Id on Line Multidisciplinary Journal and Psycology

modelos por meio dos quais os pais manejam as esferas de poder, suporte afetivo na relação com os filhos. Este ainda tem implicações no desenvolvimento psicossocial, afetando o estabelecimento de metas referente ao contexto profissional.

Os estilos parentais podem ser classificados como: democrático onde os níveis de exigências e responsividade são elevados; autoritário onde há uma discrepância entre os níveis, encontrando-se esta última reduzida; indulgente com a apresentação da responsividade elevada e a exigência reduzida, e por fim o estilo negligente onde ambas dimensões se apresentam reduzidas (MAGALHAES; ALVARENGA; TEIXEIRA,2012). Considera-se como o estilo parental mais eficaz, o democrático devido à relação de respeito e reconhecimento da individualidade estabelecida, e a propiciação de orientações.

Percebe-se, porém, em estudos realizados que crianças com pais que apresentam estilos democráticos desenvolvem características ligadas ao comportamento exploratório, confiança e engajamento acadêmico bem-sucedido. Em contrapartida os adolescentes cujo pais tinham estilo autoritário demonstravam indecisão frente a escolha de carreira profissional, uma vez que tiveram maiores dificuldades na construção da identidade pessoal (MAGALHAES; ALVARENGA; TEIXEIRA, 2012).

Outro aspecto apontado pelos autores é o equilíbrio na relação de apego e separaçãoindividuação entre pais e filhos, para que os últimos se sintam seguros frente os impasses da escolha profissional. Ressalta-se que apesar dos apontamentos, não se pode medir a qualidade da escolha tomando por princípio apenas a relação entre decisão/ indecisão.

Assim como Soares(2002) estabeleceu uma relação entre a profissão e a posição dos filhos na família, Teixeira e Hashimoto(2005) também a propõe, apontando outra de igual importância entre o significado do nome próprio e a escolha profissional, a partir de uma perspectiva psicanalítica. Postulam que as expectativas da família, a missão,o papel a ser desempenhado e o lugar a ser ocupado são designados através da atribuição do nome próprio, estando estes aspectos presentes no imaginário familiar, afetando consequentemente o processo decisório. Portanto, endossam práticas que abordem o contexto familiar e estritamente o inconsciente familiar para possibilitar ao adolescente um maior conhecimento dos aspectos emocionais mais intrínsecos que exercem influência em suas mais variadas escolhas.

Compreende-se, portanto, que independente do arranjo familiar às figuras parentais se constituem como as referências primordiais no processo de escolha. Este fato é apresentado como justificativa para o atendimento a família no processo de Orientação Profissional, pois a ansiedade e insegurança vivenciadas pelos pais afeta a tomada de decisão do adolescente (ALMEIDA; PINHO, 2008). 
Id on Line Revista Multidisciplinar e de Psicoloqia

Id on Line Multidisciplinary Journal and Psycology

Em meio à construção de sua personalidade o adolescente vivencia a desconstrução da imagem ideal de seus pais, estabelecida na infância. A ambivalência afetiva apresentada pelo adolescente pode gerar ou acentuar os conflitos no ambiente familiar. Surge a necessidade de estabelecer novas relações, onde os pais estimulem a busca por independência, autonomia (PEREIRA, 2005).Almeida e Pinho (2008)mencionam as especificidades do processo decisório de adolescentes cujos pais tenham falecido ou passado pelo processo de separação, abordando os processos de luto e de identificação, tomando por base as pesquisas de Levenfus e Soares (2002).

Considerando a função exercida pela família, é pertinente apontar que esta não é o único grupo a exercer influencias no processo decisório do adolescente. As amizades estabelecidas nos grupos de pares se apresentam como fator de influência. Devido os vínculos familiares sofrerem mudanças, os adolescentes tendem a estreitar as relações com os companheiros, exercendo influência no grupo e sendo por este influenciado (PEREIRA, 2005; PEREIRA; GARCIA,2007).

A incerteza sobre o lugar social a ser ocupado e os sentimentos decorrentes desta, pode se constituir como uma das causas para esse estreitamento. $\mathrm{O}$ grupo de pares desempenha uma função importante no processo de definição da identidade e na sociabilidade ofertando suporte emocional e social. Sendo a construção da identidade profissional um aspecto a compor a identidade pessoal, esta também sofre influencias. Porém, a relação entre grupo de pares e suas implicações na escolha profissional é abordada superficialmente nos processos de orientação Profissional (PEREIRA, 2005; PEREIRA; GARCIA,2007).

Por serem suscetíveis a opiniões alheias, os adolescentes podem conceber, erroneamente, o processo de Orientação Profissional como um espaço propicio para recebe-las, onde encontrará alguém para direcionar suas escolhas (SANTOS, 2005). Mesmo estando exposto à opiniões, estes não tem uma percepção acurada sobre a influencias de seus pares sobre suas escolhas. Na pesquisa realizada por Pereira e Garcia (2005) com 96 adolescentes se conclui que os companheiros participam explicitamente do processo decisório, através de trocas de informações sobre as opções profissionais, suporte afetivo entre outros aspectos. Os dados apontaram para os processos psicossociais envolvidos na relação estabelecida entre o grupo de pares, dentre estes a cooperação (PEREIRA; GARCIA,2007).

Vale ressaltar que a maneira como se estabelece a relação entre o adolescente e o meio familiar, mais especificamente a vinculação entre este e os pais, afeta os relacionamentos no grupo de pares(ROCHA; MOTA; MATOS, 2011).

Em referências aos fatores educacionais, a escola é considerada como um dos principais fatores de influência. As mudanças na educação brasileira a têm afetado, atingindo também os processos decisórios dos indivíduos que dela participam. Frente às diversas exigências do mundo do trabalho, a educação tem assumido um papel central, com a função de preparar os indivíduos para que 
Id on Line Revista Multidisciplinar e de Psicoloqia

Id on Line Multidisciplinary Journal and Psycology

estes possam adentrar no contexto laboral. Porém a prática de Orientação Profissional ainda se encontra distante da instituição escolar. Aparentemente há uma discrepância entre os mundos do trabalho e da escola, o que não permite a Orientação profissional cumprir sua função concernente as escolhas profissionais, a partir da integração dos fatores ligados às mesmas(ALMEIDA; MAGALHAES, 2011; SZAJDENFISZ, 2008; UVALDO; SILVA, 2010).

A escola é considerada como um significante espaço de socialização juntamente com a família, assumindo até mesmo funções que anteriormente pertenciam a esta última. Portanto cabe a ela também estar atenta ao fato que, em seu espaço se constrói projetos profissionais, e consequentemente buscar reconhecer quais fatores exercem influencias sobre os projetos de seus alunos (LEHMAN, 2010).

O primeiro Serviço Público de Orientação Educacional e Profissional ofertado no Brasil foi em 1931; e posteriormente, em 1942 regulamentou-se a profissão de Orientador Educacional, que dentre do rol de atividades, situava-se o auxílio no processo de decisão ocupacional; fazendo com que o ensino profissionalizante marcasse o início da Orientação Profissional no país (UVALDO; SILVA, 2010).

De acordo com os referidos autores para exercerem suas funções de orientação Profissional, os orientadores educacionais utilizavam os "testes vocacionais", compostos pelos testes de inteligência, inventário de interesses, entre outros. Novas formas de conduzir o processo emergiram após a publicação da Lei de Diretrizes e Bases da Educação (LDB) em 1961, que delegou também ao Orientador Educacional a atividade de Orientação Profissional, além de estabelecer a presença do mesmo em escolas de Ensino Médio, independentes de estas serem técnicas.

Em 1973 sua prática vincula-se a Pedagogia e tem sob suas competências a organização do processo de Orientação Profissional; entretanto já havia sido assentado que caberia apenas aos psicólogos a utilização dos instrumentos psicométricos. Vale destacar que neste momento a psicologia ocupava-se da questão concernente a escolha profissional, a partir da psicologia clínica. Ferreti (1988, apud UVALDO; SILVA, 2010.p. 33) aponta que as ações dos psicólogos se voltavam para os aspectos psicológicos da escolha. Os autores afirmam ainda que atualmente a Orientação profissional no Brasil está sob o domínio da Psicologia, e que a mesma se utiliza do modelo clínico no ambiente escolar, e este por muitas vezes é de caráter privado.

Os orientadores educacionais preocupavam-se com a promoção de reflexões sobre o processo de orientação, não se detendo apenas ao momento da escolha, propondo a instituição do professor como recurso para este trabalho, uma vez que este estava em contato direto com o corpo discente. Para alcançar tal objetivo, se incluiu no currículo disciplinar do Ensino Médio a disciplina de Programa de 
Id on Line Revista Multidisciplinar e de Psicoloqia

Id on Line Multidisciplinary Journal and Psycology

Informação Profissional. Entretanto não se alcançou êxito, devido à falta de implicação dos corpos discente e docente, respectivamente (UVALDO; SILVA, 2010).

De acordo com o que foi postulado por Lehamn (2010) considerando a influência da escola no processo de orientação profissional as autoras Crestani (2010) e Valore (2010) discutem a temática nas escolas de caráter privado e público, respectivamente.Abordando a Orientação Profissional como uma das temáticas de maior importância no que diz respeito a relação entre o cotidiano escolar e o mundo do trabalho, Crestani (2010) discute a temática ligada a escola privada, a partir da realização de uma pesquisa em 2007, com 52 escolas privadas do ensino médio de Porto Alegre e interior do estado do Rio Grande do Sul. Com resultados da pesquisa inferiu-se que as escolas que ofertam Orientação profissional têm uma estrutura adequada concernente ao quadro de funcionários e a metodologia utilizada. Devido à resistência em participar da pesquisa se inferiu que as escolas não se atentaram para a relevância do processo em questão.

Comparou-se os resultados obtidos com os dados de outra pesquisa realizada em 1990, e se conclui que não houveram muitas mudanças nas áreas da Psicologia Escolar e da Orientação Educacional. As práticas decorrentes destas áreas, dão ares de não priorizar a preparação para o ingresso no mercado de trabalho, não percebendo ainda o caráter preventivo que esta ação pode assumir (CRESTANI, 2010).No Brasil a Orientação Profissional constitui-se como uma prática direcionada para as classes médias e altas. Apesar da adoção da perspectiva crítica para problematizar o campo de atuação embasado pela visão liberal, o processo decisório das classes pobres não se tornou um fato de interesse a ser explorado pelos teóricos da área (BOCK, 2010).

Na discussão sobre Orientação Profissional na escola pública se pode elencar os objetivos que a mesma pretende alcançar. Como objetivo principal, se estabelece o suporte para a escolha profissional aliado a formação da identidade profissional; e propõe outros como possibilitar a confrontação das fantasias sobre as perspectivas do contexto profissional, incitar a busca de informações e promover reflexão sobre o papel profissional na sociedade e sua implicação no desenvolvimento de relações humanas saudáveis (VALORE, 2010).

A discussão levantada por Valore (2010) traz elementos que fazem menção as instâncias que foram classificadas por Guichard (2011) como componentes do processo em questão, a saber, informação, orientação e aconselhamento. Com referência ao nível informativo as autoras Levenfus e Nunes (2010) também consideram que para um processo de orientação efetivo, este deve ser assegurado, pois o comportamento exploratório apresentado na adolescência auxiliará o adolescente na aquisição de informações em seu processo decisório. Porém, devido às necessidades sociais, os jovens de classes menos privilegiadas tendem a fazer escolhas que oportunizem a ascensão na pirâmide social, não considerando aspectos individuais como interesses, preferências, aptidões e habilidades.As 
Id on Line Revista Multidisciplinar e de Psicoloqia

Id on Line Multidisciplinary Journal and Psycology

autoras afirmam ainda sobre a constância em se encontrar jovens que desconhecem a profissão que intentam escolher, uma vez que a busca por informações profissionais pode ser considerada assistemática e sem planejamento.Para que o adolescente possa fazer uma escolha contextualizada e adequada em um dado momento sócio histórico, é necessário a integração entre este e as esferas familiar e escolar, para que a partir da integração o mesmo possa obter autoconhecimento e conhecimento sobre o mundo do trabalho(LEVENFUS; NUNES, 2010; SZAJDENFISZ, 2008).

Somada a crise da adolescência, o adolescente vivencia ainda quatro circunstancias inerentes ao processo de Orientação Profissional, que se diferenciam pela forma de ansiedade, defesa e conflito (NEIVA, 2013). A primeira situação é denominada de pré-dilemática onde há a apresentação da ambiguidade com relação aos conflitos, o nível de ansiedade é baixo e as defesas são intensas uma vez que não houve percepção da necessidade da escolha. Na segunda fase, dilemática, ainda se faz presente a ambiguidade com relação aos conflitos, o nível de ansiedade é moderado, existindo percepção da necessidade da escolha, porém não há discernimento sobre os aspectos referentes a mesma.

Na terceira situação intitulada como problemática, o adolescente se encontra preocupado e apresenta o discernimento mais acurado com relação à escolha, não havendo alteração no nível de ansiedade. A última circunstancia é a de resolução; onde existe a tentativa de solucionar os conflitos para a realização da escolha, por meio da elaboração de lutos e renuncias. A vivência de sentimentos de responsabilidade, solidão e onipotência faz com que ocorra a renúncia temporária da escolha realizada. Este comportamento configura-se como uma defesa decorrente da ansiedade ocasionada pelo processo (NEIVA, 2013).

\section{Escolha e Identificação}

A escolha profissional aponta para as identificações existentes entre o adolescente e os pais, mesmo nas situações onde este tende a não aliar suas escolhas profissionais à influência familiar. $\mathrm{O}$ cenário edípico vivenciado na infância apresenta-se novamente durante a adolescência, o que provoca a reorganização do processo identificatorio. Na busca por construir sua identidade, conquistar seu espaço na rede de significações, o adolescente vivencia uma situação de luto com relação a infância e ao distanciamento do pais e a ambiguidade afetiva, entre amor e ódio em relação a estes, o que traz uma conotação depressiva à experiência de escolher. Neste contexto, optar por uma profissão pode acarretar ao sujeito o sentimento de estar contrariando a alguém, ou seja, os pais; e na tentativa de 
Id on Line Revista Multidisciplinar e de Psicoloqia

Id on Line Multidisciplinary Journal and Psycology

manter uma relação com estes marcada pelo amor, identifica-se com eles, quer seja correspondendo às expectativas ou perpetuando seus ideais (SOARESet al, 2010).

No âmbito da orientação profissional a dramática constituída pelo desejo do sujeito adolescente, identificações e a escolha a ser realizada, deve ter o seu espaço assegurado, para que seja possível ao orientando conhecer as motivações subjacentes ao seu processo decisório.

A identificação imaginaria designa a estruturação do eu, iniciada no estádio do espelho. Segundo a concepção lacaniana é por meio deste estádio que se faz possível ao sujeito a percepção unificada do seu corpo podendo diferenciá-lo daquilo que não é o seu corpo. O eu será constituído pelas imagens que permitem seu reconhecimento próprio, a saber o reconhecimento da significação sexual na forma humana. Neste processo está implicado a noção de narcisismo secundário, designando a posição do eu como objeto para a libido. A passagem do narcisismo primário para o secundário dá-se pelas imposições e expectativas socioculturais, que se apresentam ao sujeito intermediadas pelos pais, lançando este frente ao ideal do eu.

Apesar das dificuldades em seu processo de elaboração em psicanálise o conceito é classificado entre os mais importantes nas teorias freudiana e lacaniana.Freud propôs a identificação como um processo que ocorre na instancia inconsciente, a saber entre duas instancias inconscientes, não podendo ser percebido diretamente. Nessa perspectiva a relação de identificação se dá, em termos psicanalíticos, entre o eu e o objeto, onde o primeiro se assemelha a característica do segundo (ROUDINESCO,1998; NASIO,1997).

$\mathrm{Na}$ teoria freudiana o processo identificatório foi classificado em duas categorias: total e parciais. A primeira categoria foi intitulada como identificação primária, fazendo menção ao mito da horda primeva e o pai totêmico seria o objeto de identificação. Na segunda modalidade a identificação ocorreria com uma característica parcial do objeto podendo ser o traço, imagem ou emoção. $\mathrm{Na}$ vertente lacaniana, a identificação pode ser concebida como um processo que propicia o surgimento de um novo campo psíquico; categorias também são estabelecidas, a saber: identificação simbólica no que se refere ao sujeito do inconsciente, identificação imaginaria em relação ao eu e por fim identificação fantasística designando um complexo psíquico(NASIO,1997). Para a compreensão da escolha profissional, se faz relevante o entendimento da categoria freudiana de identificação parcial com a imagem do objeto que corresponde na perspectiva lacaniana a identificação imaginaria do eu com a imagem com outro. 
Id on Line Revista Multidisciplinar e de Psicoloqia

Id on Line Multidisciplinary Journal and Psycology

\section{Análise e Discussão}

Dos 14 artigos selecionados, seis artigos foram de 2005, três do ano de 2007, um do ano de 2008,um do ano de 2010, dois do ano de 2011 e um do ano de 2012. Observa-se a ausência de publicações nos anos de 2006,2009, 2013 e 2014, e um número maior de pesquisas em 2005 e 2007. Com relação à quantidade de autores por artigo: quatro foram produzidos por um autor, seis produzidos por dois autores e quatro artigos com três ou mais autores, sendo sete o número máximo, de autores por trabalho. A análise do tema será realizada por meio de três categorias: 1- Adolescência; 2- Fatores de influência no processo de escolha; 3 - Identificação.

\section{Categoria 1 - Adolescência}

Nesta categoria foram agrupados os artigos que discutiram sobre o período da adolescência. Lara et al (2005), Teixeira e Hashimoto (2005), Almeida e Pinho (2008) e Santos (2005) conceituam a adolescência como um período evolutivo do desenvolvimento humano, situado entre a infância e a vida adulta, marcado pelo aparecimento de mudanças corporais e psicológicas. Apresentam a ideia de crise a ser vivenciada para alcançar o mundo adulto, embasada por processos de lutos subjacentes utilizando-se de termos como equilíbrio/ desiquilíbrio, instabilidade e reorganização. Os sentimentos de angustia, medo, insegurança, duvida, ansiedade, e a falta de autoconfiança são citados como recorrentes na vivencia adolescente (BARRETO E AIELLO-VAISBERG, 2007). A construção da identidade, a busca pela autonomia e o imperativo da escolha profissional são consideradas como tarefas inerente à fase.

Diferentemente do enfoque dado pelos autores citados, Coutinho(2005) e Frota (2007) abordam a adolescência como um conceito, inaugurado na modernidade e portanto, tecido historicamente. Frota (2007) critica a naturalização de características utilizadas para a definição da adolescência, afirmando que esta não deve ser abordada apenas como um período de transição e que sua compreensão se dá por meio de sua historicidade. Coutinho (2005) analisa a valorização dada às noções de liberdade e autonomia e como estas se articulam a construção da adolescência e como os demais autores, relata a necessidade da escolha profissional e os impasses enfrentados para fazê-la. As autoras nomeiam a adolescência como um ideal cultural almejado pela sociedade contemporânea, o que torna o processo de envelhecimento árduo.

Coutinho(2005)propõe ainda a compreensão deste ideal como um sintoma social característico da contemporaneidade, um contexto caracterizado pelo consumismo e a ideologia liberal, relacionado 
Id on Line Revista Multidisciplinar e de Psicoloqia

Id on Line Multidisciplinary Journal and Psycology

às dificuldades de transmissões de referências simbólicas que possam compor o processo identificario dos indivíduos que estão saindo da infância. Assim, considerando a adolescência sob um prisma sócio histórico, não é cabível utilizar o termo adolescência, mas adolescências, frente a multiplicidade de realidades onde este conceito se constrói.

\section{Categoria 2- Fatores de influência no processo de escolha profissional}

Foram enquadrados nesta categoria os artigos que se propuseram a discutir sobre os fatores que exercem influenciam no processo de escolha profissional. São considerados como fatores de influência para a escolha profissional: aspectos individuais, sociais, culturais, políticos, econômicos, tecnológicos, familiares e os psicológicos, referindo-se a relação com os pares (SANTOS, 2005; ALMEIDA; PINHO, 2008; ALMEIDA; SILVA, 2011; MAGALHAES et al, 2012). Dentre estes fatores os mais discutidos são os familiares e a relação com os pares.

A família é o núcleo onde o adolescente busca por referenciase enquanto fator de influência pode auxiliar ou dificultar a escolha profissional. As influencias podem ser manifestas de forma explicitas ou sutis.(SANTOS,2005; ALMEIDA; PINHO,2008; LARAet al, 2005; TEIXEIRA; HASHIMOTO, 2005; ALMEIDA; MAGALHÃES, 2011).

Magalhaes, Alvarenga e Teixeira (2012)investigando a relação entre estilos parentais, instabilidades de metas e indecisão vocacional, concluíram que a magnitude da influência do estilo parental não foi expressiva, porem os resultados da pesquisa apontaram para os problemas enfrentados no estabelecimento de metas por filhos de pais negligentes.

Almeida e Silva (2011)e Almeida e Pinho(2008) discorrem sobre a importância da participação dos pais no processo de Orientação Profissional, uma vez que os pais também vivenciam os conflitos e ansiedade frente à tomada de decisão dos filhos. De acordo com os autores o processo possibilitaria aos pais reflexões sobre o modo como lidam com a situação e a percepção de suas influencias sobre a escolha do filho.Teixeira e Hashimoto (2005) discutem a influência familiar na escolha profissional por meio da atribuição dos nomes próprios. Afirmam que no contexto familiar é designado a cada indivíduo uma missão e a análise do espaço(primogênito, caçula) e do nome pode trazer a compreensão da mesma.

Sobre a vinculação aos pares, Pereira e Garcia (2007) enunciam que a mesma não é abordada de maneira eficaz pelos autores brasileiros e com o intuito de compreender a atenção dedicada prioritariamente ao contexto familiar, os autores apresentam como hipóteses a existência de uma vertente ideológica na Psicologia brasileira e a falta de conhecimento por parte dos pares, de seu poder 
Id on Line Revista Multidisciplinar e de Psicoloqia

Id on Line Multidisciplinary Journal and Psycology

de influência.A pesquisa realizada pelos autores revelou que o processo de cooperação é mais expressivo que o de influência, em relação à amizade e a escolha profissional.

\section{Categoria 3. Identificação}

Foram alocados nesta categoria os artigos que se propuseram a discorrer sobre o processo de identificação. Coutinho et al (2005); Coutinho (2005); e Soares et al (2010) partilham do conceito de identificação como ligação afetiva entre duas pessoas, onde uma ocupa o lugar de referência de ideal, proposto pela teoria freudiana para o embasamento de suas discussões.

Coutinho et al (2005) discute a identificação na adolescência, partindo da explanação do conceito de Ideal do eu e Representação social, articulando a teoria psicanalítica e psicologia social. Abordam a influência midiática através dos meios de comunicação na subjetivação dos adolescentes ao elegerem figuras de referência, admiração, nas quais depositam os ideais que outrora pertencia à esfera familiar.

Coutinho (2005) lança mão do conceito de ideal para discutir a experiência adolescente na contemporaneidade, e assim como Coutinho et al (2005) afirma que as figuras eleitas na esfera social são vazias e/ou distantes, a autora também descreve um esvaziamento dos ideais sociais. Alertando para a fragmentação das referências simbólicas no meio social, a autora aborda a complexidade vivenciada pelos adolescentes no estabelecimento de identificações, e como esse fator incide sobre a construção da identidade profissional.Soares (2010) relaciona o processo de identificação com a escolha profissional, afirmando que esta decorre necessariamente de uma base identificatoria.

\section{Considerações Finais}

O presente trabalho se propôs a investigar quais fatores exercem influência na escolha profissional do adolescente. Os fatores elencados foram: políticos, sociais, culturais, tecnológicos, econômicos, educacionais, individuais, psicológicos e familiares; sendo destacados nas produções científicas os fatores familiares e a relação com os pares, no que se refere aos fatores psicológicos.

Para alcançar o objetivo delimitado a metodologia escolhida foi a revisão sistemática por metassíntese. A pesquisa também apresentou o percurso histórico da orientação profissional, discorreu sobre a adolescência, suas motivações e relacionou o conceito de identificação, presente na teoria 
Id on Line Revista Multidisciplinar e de Psicoloqia

Id on Line Multidisciplinary Journal and Psycology

psicanalítica, com o processo decisório. Apesar do empenho empregado na investigação, os apontamentos realizados não provocaram o esgotamento do tema, uma vez que as bases de dados utilizadas não comportavam todas as produções sobre mesmo. Dificuldades foram encontradas para a realização da análise dos dados no que se refere ao estabelecimento das categorias e articulação entre os autores, fato que decorre da inexperiência da pesquisadora.

Abordar o processo de escolha profissional a partir da vivência do sujeito adolescente permitiu conhecer as carências existentes no campo da Orientação Profissional referente a vertente prática, revelando que apesar de sua evolução no cenário brasileiro, a área requer ainda pesquisas que tragam consigo delineamentos de intervenções, uma vez que as produções científicas asseguram a importância do ambiente familiar na constituição do sujeito e sua influência para a escolha profissional, entretanto há carências de proposições para o envolvimento das figuras familiares.

A hipótese levantada inicialmente sobre quais fatores seriam preponderantes para a escolha profissional foi confirmada, porém nutria-se a expectativa de que as pesquisas selecionadas discorressem mais sobre os demais fatores que influem na escolha profissional, além dos familiares e psicológicos, como por exemplo, fatores educacionais e políticos. Em relação ao contexto educacional, a presente pesquisa ressalta a pertinência da capacitação de educadores/professores para transformarem as práticas em Orientação Profissional comum ao ambiente escolar, não se restringindo aos anos finais do ensino médio ou a iminência dos vestibulares, mas uma temática discutida desde as series iniciais de acordo com as necessidades de cada público.

Os dados propiciados pela pesquisa possibilitaram a uma compreensão mais crítica da adolescência, como um fenômeno para além de uma perspectiva biológica, fisiológica e/ou psicológica apontando para a construção sociocultural do conceito e sua manifestação na contemporaneidade e os desafios acarretados para o sujeito adolescente. Permitiu ainda ampliar o olhar sobre as relações entre a políticas e a educação e seus efeitos para a inserção das diferentes classes no mundo do Trabalho.

Frente o panorama delineado, percebe-se como imprescindível que as pesquisas ligadas à área teçam discussões e reflexões sobre a(s) finalidade(s) das práticas em Orientação Profissional, articulando as mesmas com as mudanças no mundo do Trabalho, ressaltando o compromisso ético que as subsidiam e o impasse que enfrentam ao almejar orientar escolhas profissionais, decorrentes de um projeto de carreira que não se sobreponha ao projeto de vida, mas que faça parte deste. Convém ainda mencionar o desafio que se somam as perspectivas apresentadas, de traçar intervenções singulares que possibilite ao sujeito orientado refletir sobre o significado e consequiências de seu futuro exercício profissional para si e para os outros sociais que o cerca. 
Id on Line Revista Multidisciplinar e de Psicoloqia

Id on Line Multidisciplinary Journal and Psycology

\section{Referências}

ABADE, Flávia Lemos. Orientação profissional no Brasil: uma revisão histórica da produção científica. Rev. bras. orientac. prof, São Paulo, v. 6, n. 1, p. 15-24, jun. 2005. Disponível em http://pepsic.bvsalud.org/scielo.php?script=sci_arttext\&pid=S1679-

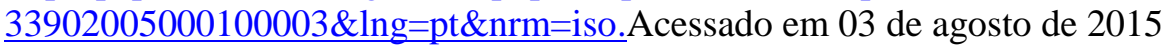

ALMEIDA, Fabiana Hilário de; MELO-SILVA, Lucy Leal. Influência dos pais no processo de escolha profissional dos filhos: uma revisão da literatura. Psico-USF (Impr.), Itatiba, v. 16, n. 1, p. 75-85, Apr. 2011 . Disponível em http://www.scielo.br/scielo.php?script=sci arttext\&pid=S1413$\underline{82712011000100009 \& \operatorname{lng}=e n \& n r m=i s o}$ Acessado em 03 de agosto de 2015

ALMEIDA, Maria Elisa Grijó Guahyba de; MAGALHAES, Andrea Seixas. Escolha profissional na contemporaneidade: projeto individual e projeto familiar. Revista Brasileira de Orientação Profissional. São Paulo, v. 12, n. 2, p. 205-214, dez. 2011.

http://pepsic.bvsalud.org/scielo.php?script=sci_arttext\&pid=S1679$33902011000200008 \& \operatorname{lng}=$ pt\&nrm=iso. Acessado em 03 de agosto de 2015.

ALMEIDA, Maria Elisa Grijó Guahyba de; PINHO, Luís Ventura de. Adolescência, família e escolhas: implicações na orientação profissional. Psicologia clinica. Rio de Janeiro v.20, n.2, p.173184,2008. Disponível em http://www.scielo.br/scielo.php?script=sci_arttext\&pid=S010356652008000200013\&lng=en\&nrm=isoAcessado em 03 de agosto de 2015.

AQUINO, Cassio Adriano Braz de. Reflexões sobre a precarização laboral: uma perspectiva da psicologia social. II jornada internacional de políticas públicas. São Luís - MA, agosto, 2005. Disponível em http://www.joinpp.ufma.br/jornadas/joinppIII/html/Trabalhos2/Cassio adriano b. Aquino219.pdf. Acessado em 03 de agosto de 2015.

BARRETO, Maria Auxiliadora; AIELLO-VAISBERG, Tania. Escolha profissional e dramática do viver adolescente. Psicol. Soc., Porto Alegre, v. 19, n. 1, p. 107-114, Apr. 2007 . Disponivel em http://www.scielo.br/scielo.php?script=sci_arttext\&pid=S0102-

$71822007000100015 \& \operatorname{lng}=e n \& n r m=$ iso Acessado em 03 de agosto de 2015. http://dx.doi.org/10.1590/S0102-71822007000100015.

BOCK, Silvio Duarte. Orientação Profissional para classes pobres.- São Paulo : Cortez, 2010.

CAMPOS, Dinah Martins de Souza. Psicologia da adolescência: normalidade e psicopatologia. 23. Ed. Petrópolis, Vozes, 2011.

COUTINHO, Luciana Gageiro et al . Ideais e identificações em adolescentes de Bom Retiro. Psicologia Social. Porto Alegre, v. 17, n. 3, p. 50-56, Dec. 2005 . Disponível em $\mathrm{http} / / / \mathrm{www}$.scielo.br/scielo.php?script=sci_arttext\&pid=S0102-

71822005000300007\&lng=en\&nrm=iso Acessado em 03 de agosto de 2015.

COUTINHO, Luciana Gageiro. A adolescência na contemporaneidade: ideal cultural ou sintoma social.Pulsional, Revista de psicanálise ano vxIII, n. 181, março/ 2005. Disponível em http://www.editoraescuta.com.br/pulsional/181_02.pdf Acessado em 03 de agosto de 2015 
Id on Line Revista Multidisciplinar e de Psicoloqia

Id on Line Multidisciplinary Journal and Psycology

COUTINHO, Maria Chalfin; KRAWULSKI, Edite; SOARES, Dulce Helena Penna. Identidade e trabalho na contemporaneidade: repensando articulações possíveis. Revista Psicologia \& Sociedade, v. 19, 2007. Disponível em https://scholar.google.com.br.Acessado em 03 de agosto de 2015.

CRESTANI, Regina Anzolch. Orientação Profissional na escola privada, In: LEVENFUS, Rosane Schotgues; SOARES, Dulce Helena Penna et al, (org). Orientação Vocacional Ocupacional. -2. Ed. - Porto Alegre :Artemed, 2010.

SANTOS, Larissa Medeiros Marinho Dos. O papel da família e dos pares na escolha profissional. Psicologia em Estudo, v. 10, n. 1, p. 57-66, 2005. Disponivel em http://www.scielo.br/pdf/\%0D/pe/v10n1/v10n1a07.pdf. Acessado em 13 de setembro de 2015.

FROTA, Ana Maria Monte Coelho. Diferentes concepções da infância e adolescência: a importância da historicidade para sua construção. Estud. pesqui. psicol.Rio de Janeiro, v. 7, n. 1, jun. 2007. Disponível em http://pepsic.bvsalud.org/scielo.php?script=sci arttext\&pid=S1808-

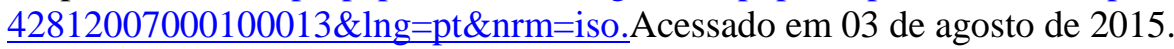

GUICHARD, Jean. Quais os desafios para o aconselhamento em orientação no início do século 21?. Rev. bras. orientac. prof, São Paulo, v. 13, n. 2, p. 139-152, dez. 2012. Disponível em http://pepsic.bvsalud.org/scielo.php?script=sci_arttext\&pid=S1679-

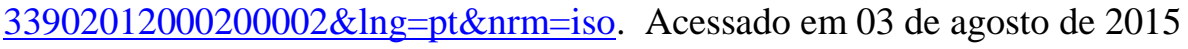

LARA, Luciane Dianin de et al. O adolescente e a escolha profissional: compreendendo o processo de decisão. Arq. ciências saúde UNIPAR, v. 9, n. 1, p. 57-61, 2005. Disponível em https://scholar.google.com.br. Acessado em 11 de setembro de 2015

LEHMAN, Yvette Piha. Orientação profissional na pós-modernidade, In: LEVENFUS, Rosane Schotgues; SOARES, Dulce Helena Penna et al, (org). Orientação Vocacional Ocupacional. -2. Ed. - Porto Alegre :Artemed, 2010.

LEVENFUS, Rosane Schotgues; NUNES, Maria Lucia Tiellet. Principais temas abordados por jovens vestibulandos centrados na escolha profissional,In: LEVENFUS, Rosane Schotgues; SOARES, Dulce Helena Penna et al, (org). Orientação Vocacional Ocupacional. -2. Ed. - Porto Alegre :Artemed, 2010.

MAGALHAES, Mauro de Oliveira; ALVARENGA, Patrícia; TEIXEIRA, Marco Antônio Pereira. Relação entre estilos parentais, instabilidade de metas e indecisão vocacional em adolescentes. Rev. Bras. Orientac. Prof, São Paulo, v. 13, n. 1, p. 15-25, jun. 2012 . Disponível em http://pepsic.bvsalud.org/scielo . Acessado em 11 de setembro de 2015.

MOURA, Cynthia Borges de. Orientação profissional sob o enfoque da análise do comportamento. 3 ed.- Campinas, SP: Editora Alínea, 2011.

NEIVA, khatia Maria Costa. Processos de escolha e orientação profissional. -2. Ed.- Campinas, SP: editora Alínea, 2013.

OLIVEIRA, Adélia et al. Metassíntese: Apontamentos para sistematização de revisões amplas e crítica interna à produção científica. CIAIQ2015, v. 1, 2015. Disponível em https://scholar.google.com.br . Acessado em 04 de abril de 2016. 
Id on Line Revista Multidisciplinar e de Psicoloqia

Id on Line Multidisciplinary Journal and Psycology

OLIVEIRA, Gisele et al. Psicologia do trânsito: uma revisão sistemática.Cad. Cult. Ciênc. Ano IX, v.13 n.2, Mar, 2015. Disponível em

http://periodicos.urca.br/ojs/index.php/cadernos/article/view/850/pdf 1 Acessado em 17 de maio de 2016.

NASIO, Juan-David. Lições sobre os 7 conceitos cruciais da psicanálise. - Rio de Janeiro:

Zahar,1997.

PAPALIA, Diana E.; FELDMAN, Ruth Duskin. Desenvolvimento humano. -12 ed.- Porto Alegre: AMGH, 2013.

PEREIRA, Fábio Nogueira; GARCIA, Agnaldo. Amizade e escolha profissional: influência ou cooperação?. Rev. bras. orientac. prof, São Paulo , v. 8, n. 1, p. 71-86, jun. 2007 . Disponível em http://pepsic.bvsalud.org/scielo. Acessado em 14 de setembro de 2015.

ROCHA, M.; MOTA, C. P.; MATOS, P. M.Vinculação à mãe e ligação aos pares na adolescência: O papel mediador da autoestima. Análise Psicológica, Lisboa, v. 29, n. 2, p. 185-200, abr. 2011. Disponível em http://www.scielo.mec.pt/scielo.php?script=sci_arttext\&pid=S0870-

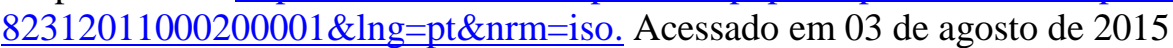

RIBEIRO, Marcelo Afonso; UVALDO, Maria da Conceição Coropos. Frank Parsons: trajetória do pioneiro da orientação vocacional, profissional e de carreira. Rev. bras. orientac. prof, São Paulo, v. 8, n. 1, p. 19-31, jun. 2007 . Disponível em http://pepsic.bvsalud.org/scielo Acessado em 14 de setembro de 2015 .

ROUDINESCO, Elisabeth. Dicionário de psicanálise. - Rio de Janeiro : Zahar, 1998.

SILVA, Mariita Bertassoni da. A formação do orientador profissional. Revista ABOP, Porto Alegre, v.3, n.1, p.161-165, jun. 1999. Disponível em http://pepsic.bvsalud.org/scielo. Acessado em 11 de setembro de 2015 .

SOARES, Dulce Helena Penna. A escolha profissional : do jovem ao adulto. - São Paulo: Summus, 2002.

SOARES, Dulce Helena Penna; AGUIAR, Fernando; GUIMARAES, Beatriz da Fontoura. O conceito de identificação no processo de escolha profissional. Aletheia, Canoas , n. 32, p. 134-146, ago. 2010. Disponível em http://pepsic.bvsalud.org/scielo.php?script=sci arttext\&pid=S1413-

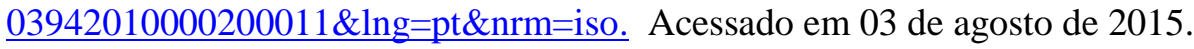

SPARTA, Mônica. O desenvolvimento da orientação profissional no Brasil. Rev. bras. orientac. prof, São Paulo, v. 4, n. 1-2, p. 1-11, dez. 2003 . Disponível em http://pepsic.bvsalud.org/scielo.php?script=sci_arttext\&pid=S1679-

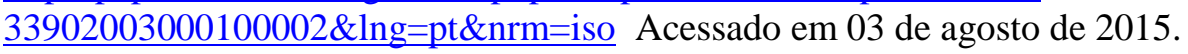

SZAJDENFISZ, Bela Malvina. O adolescente e suas escolhas: contribuições da psicanálise para a escolha profissional. 2008. Disponível em http://www.uva.br/mestrado/dissertacoes_psicanalise/17_BELA_MALVINA_SZAJDENFISZdissertacao_para_encadernar_bela_malvina.pdf. Acessado em 13 de setembro de 2015.

TEIXEIRA, Marco Antônio Rotta; HASHIMOTO, Francisco. Família e escolha profissional: A questão espacial, temporal e o significado dos nomes. Pulsional Revista de Psicanálise, v. 18, n. 182, 
p. 63-73, 2005. Disponível em http://www.editoraescuta.com.br/pulsional/182 06.pdf. Acessado em 03 de agosto de 2015.

UVALDO, Maria da Conceição Coropos; SILVA, Fabiano Fonseca da. Escola e escolha profissional: um olhar sobre a construção de projetos profissionais,In: LEVENFUS, Rosane Schotgues; SOARES, Dulce Helena Penna et al, (org). Orientação Vocacional Ocupacional. -2. Ed. - Porto Alegre :Artemed, 2010.

VALORE, Luciana Albanese; Orientação Profissional em grupo na escola pública, In: LEVENFUS, Rosane Schotgues; SOARES, Dulce Helena Penna et al, (org). Orientação Vocacional Ocupacional. -2. Ed. - Porto Alegre :Artemed, 2010.

\section{Como citar este artigo (Formato ABNT):}

ANDRADE, M.M; MARANHÃO, T.L.G.; BARBOSA, J.S.; BATISTA, H.M.T.; SANTANA, A.O. Adolescência, Escolha profissional e Identificação: Uma Revisão Sistemática. Id on Line Revista Multidisciplinar e de Psicologia, Julho de 2016, vol.10, n.30, Supl 3, p. 178-204 . ISSN 1981-1179.

Recebido: 25/06/2016

Aceito: 03/07/2016 